\title{
ROOTING RESPONSES OF FEMALE AND MALE CUTTINGS \\ OF LEUCADENDRON ELIMENSE E. PHILLIPS SUBSP. ELIMENSE ON THE TYPE AND CONCENTRATION OF AUXIN
}

\author{
Short communication \\ Jenny LIEDTKE, Muhali JIMOH*(D), Charles LAUBSCHER \\ Cape Peninsula University of Technology, South Africa
}

Received: January 2021; Accepted: July 2021

\begin{abstract}
Female and male plants of difficult-to-root species Leucadendron elimense subsp. elimense were investigated for rooting potential with three rooting hormones: indole-3-acetic acid (IAA), 1-naphthaleneacetic acid (NAA), and indole-3-butyric acid (IBA) at three different concentrations (2000 ppm, 4000 ppm, and $6000 \mathrm{ppm}$ ). The experiment was made under essential misting, bottom heat, and a naturally ventilated greenhouse. After 18 weeks the experiment terminated and callusing and rooting percentage, root number, and root length were determined. Female cuttings rooted in the highest percentage (80\%), root number $(>30)$, and root length (close to $100 \mathrm{~mm}$ ) after treatment with IAA at $4000 \mathrm{ppm}$. Under the above treatment male cuttings rooted in $70 \%$, with a mean root number of 24 and root length of $90 \mathrm{~mm}$. The efficient rooting results could aid in saving the species in its natural habitat and supporting restoration ecology, as well as introducing this species into the flower market.
\end{abstract}

Key words: callusing, interaction between gender and rooting hormones, rooting hormones

\section{INTRODUCTION}

Leucadendron elimense subsp. elimense is an endemic species of the Proteaceae family, found along the road from Elim to Bredasdorp in the Overberg region, South Africa, and more specifically from the town of Elim, arising to the epithet name of the species (Mustart et al. 1997; Rebelo 2001; Carolus \& Porter 2008). The habitat of L. elimense in the southwestern part of the Western Cape Province fynbos biome encompasses fynbos and Renosterveld species. This biome has little structural diversity as three plant families dominate the area, namely the Proteaceae, Ericaceae, and the Restionaceae (Tansley \& Brown 2000; Born et al. 2007). Over 7000 plants can be found in the fynbos biome, of which over $80 \%$ are endemic to the region, mostly growing on well-leached Cape sandstone soil (Rebelo 2001). Harvesting of this species from natural habitats is illegal since it is on the Red List and its status is endangered, therefore it has become important to investigate its potential using vegetative propagation (Rebelo 2001; Carolus \& Porter 2008).
The species is dioecious, with a clear distinction between male and female plants. Female plants have only a few branches to a growth height of $1.5 \mathrm{~m}$ on single stems compared to more multibranched stems from male plants (Rebelo 2001; Carolus \& Porter 2008). The leaves of the species are elliptic and slightly larger in female plants, reaching a length of $14-57 \mathrm{~mm}$ and width of 7$21 \mathrm{~mm}$, whereas leaves from male plants grow up to 13-49 mm long and 5-19 mm wide (Rebelo 2001). Both male and female plants have yellow involucral leaves which overlap the base of the flower head. Flowers appear from July to September and the fruits and cones develop in February (Hall \& Veldhuis 1985; Carolus \& Porter 2008).

The species mainly reproduces from seeds in its natural habitat. The pungent smell of the male and female flower heads indicates that they are insectpollinated by flies and beetles and the main pollinator is the monkey beetle (Clania glenlyonensis) (Carolus \& Porter 2008). L. elimense is also known as the Elim cone bush, and belongs to the crown cone bushes, subsection Ventricosa. The crown cone bushes have 
hairless seeds that bulge outward on one side and go inward on the other, they have a ridged perimeter (Rebelo 2001). The cone bracts are free from one another, and all species in this group release their seeds after five months of ripening (Ben-Jaacov \& Silber 2006).

Germination of the seed is fire-dependent to ensure that the species reproduction cycle is completed. Proteaceae fynbos must burn at an age of 6 to 45 years to propagate (Brown \& Botha 2004). Some species are either resprouters or reseeders, meaning they either grow again from an existing plant or they grow from seed after a fire. The reseeders either keep their seeds safe in a cone until a fire occurs or drop them after a few months, and ants bury them in the ground to keep them safe from rodents and consumption by fire (Brown \& Botha 2004; Holmes \& Newton 2004).

L. elimense grows inland, meaning at least two kilometers from the coast at an altitude between 20 to 200 meters. It grows in shallow soils which have ferricrete over clay (Carolus \& Porter 2008). The Elim ferricrete fynbos can be found in low-lying areas from Botrivier to De Hoop and this species remains threatened, critically endangered due to alien invasive species, land transformation, and poor fire regimes. L. elimense mostly grows on south-facing slopes but can also be found on the north and west-facing slopes and a few grow on east-facing slopes (Holmes \& Newton 2004; Brown \& Duncan 2006; Curtis 2013).

Considering the economic potential of both male and female cut flowers, there have not been many attempts to cultivate these sexes individually. Earlier reports from Laubscher and Ndakidemi $(2008 \mathrm{a}, \mathrm{b})$ indicated that there is no scientific evidence that L.elimense propagates clonally, as no previous studies have been recorded on the vegetative propagation of this species. A cultivation protocol to propagate these individual-gender plants could support the commercial cultivation of the species and further reduce the species' red-listed status. This study, therefore, aimed to investigate the vegetative propagation of L. elimense female and male plants to establish which hormone treatment would be most suitable for which gender plant. The commercial value of this species has further potential for the cut flower industry as much of its potential remains unexplored and underexploited, mainly due to the unavailability of saleable plants.

\section{MATERIALS AND METHODS}

\section{Greenhouse experiment and environment}

The experiment was conducted from 23 May until 24 September 2019 in the propagation greenhouse on the Cape Peninsula University of Technology, Bellville Campus South Africa. This part of the greenhouse is a semi-controlled environment (Viljoen et al. 2021). The sides of the greenhouse are made of insect-proof netting to allow for natural airflow and moisture penetrating the building; however, the roof prevented rain from above. Temperatures ranged between 15 and $26^{\circ} \mathrm{C}$ while the relative humidity ranged from 90 to $96 \%$ (Faber et al. 2020). During the rooting period, plant bags were placed on hotbeds with a temperature of $22{ }^{\circ} \mathrm{C}$ and received intermitted mist irrigation alternating every 40 minutes for 21 seconds (Nichols 2005; Malan 2012; Reinten 2014). The amount of water received per interval of irrigation measured $500 \mathrm{ml}$ during the rooting stage. Once the cuttings had rooted, they were moved to a hardening-off section where they received a mist spray every 50 minutes for 18 seconds; the amount of water received per interval of irrigation measured $150 \mathrm{~mL}$.

\section{Plant material and cutting preparation}

The plant material of L. elimense subsp. elimense was collected with permission on the land of the Elim church, a German mission station in the Western Cape Province of South Africa (Schoeman \& Visagie 2014). To ensure sustainable harvesting, the plant material was collected from randomly selected, different plants with cuttings taken from 50 female and 50 male plants. The plant material was stored in moist newspaper overnight to ensure it did not dry out. The following morning the cuttings were taken to the greenhouse and processed (Faruchi et al. 1997; Brown \& Duncan 2006). The terminal cuttings were cut into uniform lengths of $15 \mathrm{~cm}$ for female plants and $10 \mathrm{~cm}$ for male plants (Fig. 1) just below the node with a straight cut, and then sprayed with $4 \mathrm{~g} \cdot \mathrm{L}^{-1}$ of Captab (captan) fungicide manufactured by Universal Crop Protection (Pty) Ltd., South Africa. The bottom $1 / 3$ of the leaves were removed and the treatment was administered. Two hundred terminal cuttings were then planted into perforated transparent bags $125 \times 190 \mathrm{~mm}$, obtained from Packit 354, Voortrekker Road, Maitland, Cape Town, Western Cape, with a mix of an acidic, well-drained medium 
consisting of coarse river sand ( $2 \mathrm{~mm}$ diameter), coco peat, and perlite $(2: 1: 1)$. The cuttings were buried one-third deep in the substrate to ensure good aeration (Ben-Jaacov \& Silber 2006; Brown \& Duncan 2006; Reinten 2014). The plants were then placed on the hotbeds in the greenhouse and watered thoroughly.

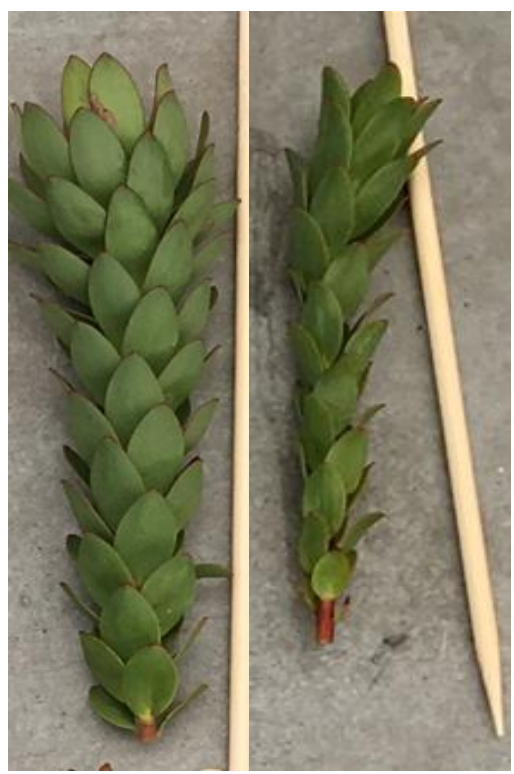

Figure 1. Cuttings of Leucadendron elimense var. elimense - female (left) and male (right)

\section{Experimental treatments}

The treatments consisted of three rooting hormones, namely indole-3-acetic acid (IAA), 1-naphthaleneacetic acid (NAA), and indole-3-butyric acid (IBA) (Sigma Aldrich) at concentrations of 2000 ppm, $4000 \mathrm{ppm}$, and $6000 \mathrm{ppm}$. The treatments were laid out in a randomized block design with ten female and ten male plants to allow for 10 repetitions for each treatment. Treatments were done with cuttings dipped in the liquid for ten seconds at a depth of one to two centimeters. The control cuttings were not treated with growth regulators.

Treatment of cuttings during the growing period Cuttings were continuously monitored for the stress of overwatering and treated weekly with a preventative fungicide spray. A ratio 1:1 of a mixture of Captab $\left(4 \mathrm{~g} \cdot \mathrm{L}^{-1}\right)$, and $5 \mathrm{~mL} \cdot \mathrm{L}^{-1} \mathrm{Kelpak}$, fertilizer containing seaweed extract, manufactured by Kelp Products (Pty) Ltd. (Simon's Town, South Africa) was sprayed on the cuttings at $12 \mathrm{pm}$ weekly (Laubscher \& Ndakidemi 2008a; Xego 2017). Overwatering, signs of blacking on leaves and stems, and rotting were monitored during the rooting period and yellow and dead leaves were removed from cuttings. At week 13, the cuttings were moved to the hardening-off condition, where they received $150 \mathrm{ml}$ of water via mist sprayers every 50 minutes for 18 seconds. The plants were sprayed weekly with a mixture of Captab $\left(4 \mathrm{~g} \cdot \mathrm{L}^{-1}\right)$ and $\operatorname{Kelpak}\left(5 \mathrm{~mL} \cdot \mathrm{L}^{-1}\right)$.

\section{Determination of plant growth parameters}

At week 18, the cuttings were removed, the substrate was carefully rinsed off the roots, and measurements were done. The callusing percentage was determined on the number of cuttings that developed successful callus tissue of parenchyma cells which covered the wounded area at the basal cut end and node of each cutting. The rooting result was presented as the number of cuttings that developed adventitious roots from the callused tissue, the number of roots, and the length of the longest root. Rooting time could vary but cuttings should root between six to sixteen weeks and develop roots that were visible on the sides of the bag as an indication that they are ready to be planted out (Brown \& Duncan 2006; Reinten 2014).

\section{Statistical analysis}

The data was analyzed by using a two-way analysis of variance (ANOVA), with the computing software program STATISTICA 13 and MINITAB 17. The occurrence of statistical differences were determined by using the Fisher's least significant difference (LSD) at values of $p \leq 0.05$ levels of significance.

\section{RESULTS}

Cuttings that were not treated with auxin did not form callus or roots, whether they were from male or female plants, and $50 \%$ of them died, also regardless of their origin. The value of rooting parameters depended on the type and concentration of auxin. Overall, the male plant cuttings took root in a higher percentage, but it was dependent on the type and concentration of auxin.

\section{Callusing percentage}

The auxin IAA at $4000 \mathrm{ppm}$ was highly successful with an $80 \%$ callusing although it was not statistically different from other treatments except for NAA 600, IBA 400 and 600 ppm (female), and IAA 6000 and NAA 6000 (male). The treatments of the 2000 and 4000 ppm IAA were most effective for callusing of male and female cuttings (Fig. 2). 


\section{Rooting percentage}

The cuttings' ability to form roots was a reflection of their ability to form callus. The greatest number of female cuttings ( $80 \%$ ) formed roots after treatment with IAA at a concentration of $4000 \mathrm{ppm}$ (Fig. 3). After treatment with IBA 4000 or 6000 , approximately $20 \%$ and $10 \%$ of the female cuttings took root and the female cuttings treated with NAA $6000 \mathrm{ppm}$ did not take root at all. Male cuttings took root in $70 \%$ after treatment with IAA 4000 and 6000 ppm, NAA 4000 and IBA 6000 ppm. Significantly fewer cuttings rooted after the IAA $6000 \mathrm{ppm}$ treatment (20\%) and after the 6000 ppm NAA treatment $(40 \%)$.

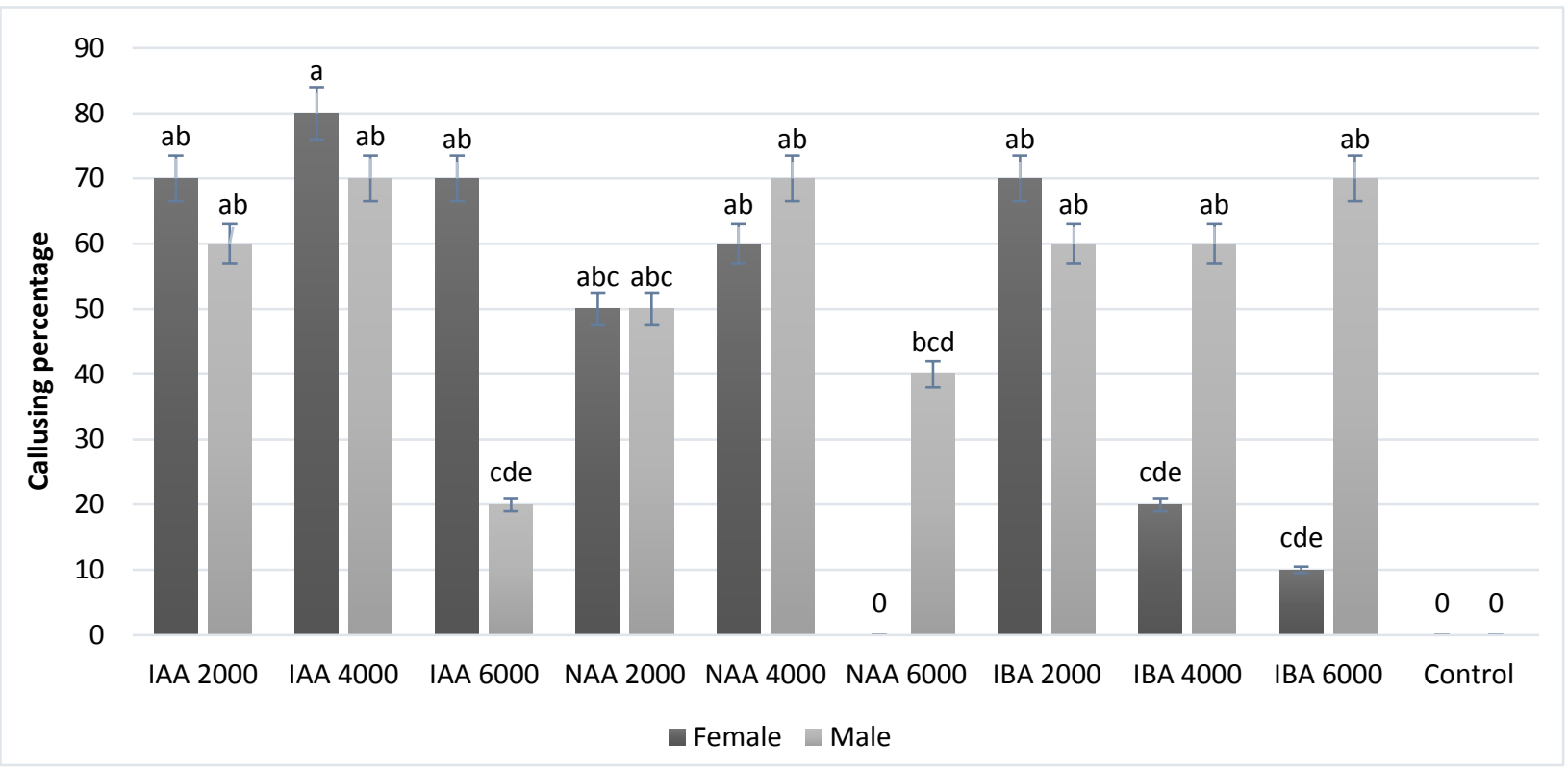

Figure 2. The effect of auxins on the callusing percentage of female and male cuttings of L. elimense. Means followed with the same letters do not differ significantly at $\mathrm{p} \leq 0.05$

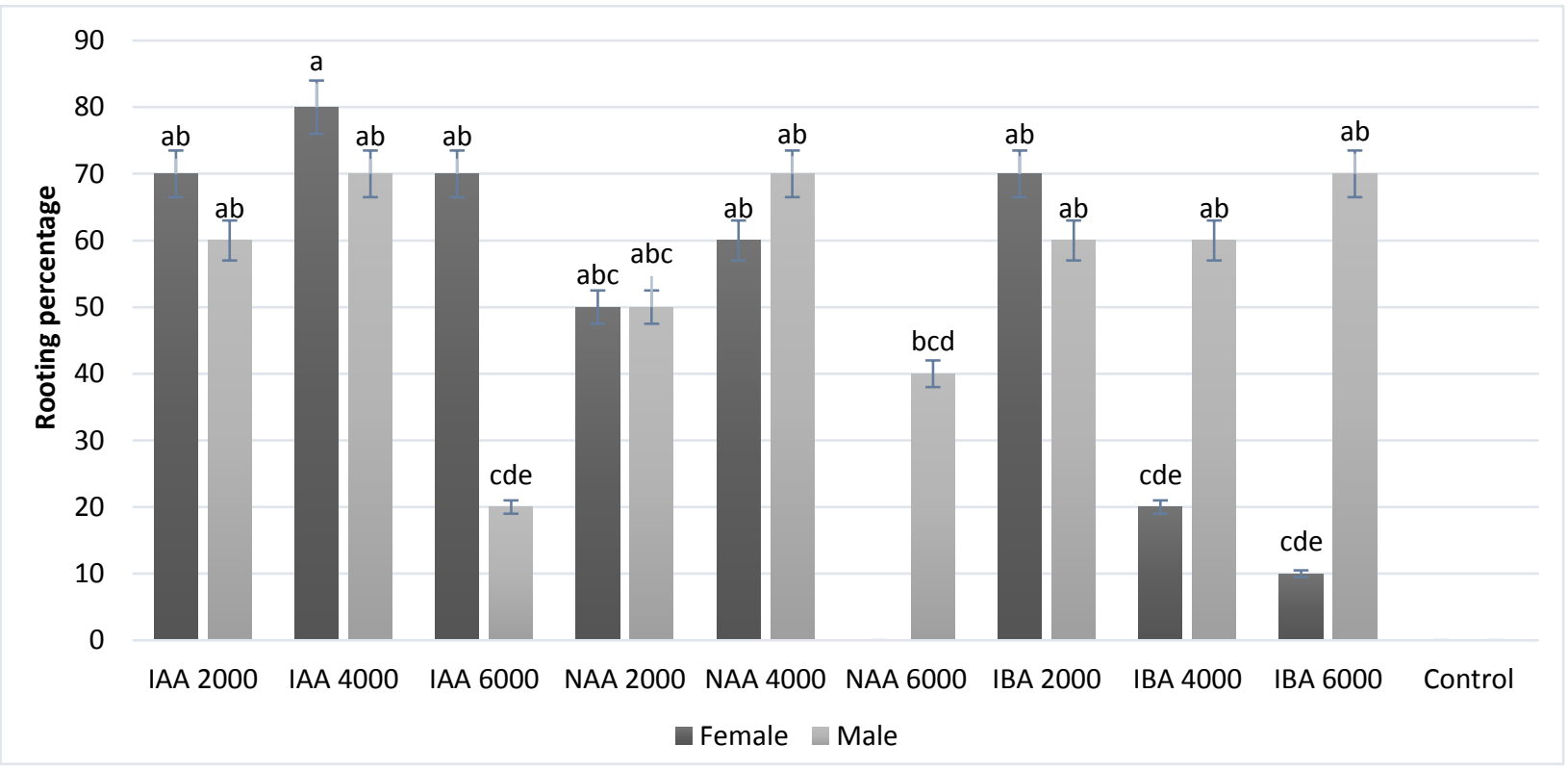

Figure 3. The effect of auxins on the rooting percentage of female and male cuttings of L. elimense. Means followed with the same letters do not differ significantly at $\mathrm{p} \leq 0.05$ 


\section{Number of roots}

The greatest number of roots on female cuttings (over 30) was formed after the IAA treatment of 4000 ppm (Fig. 4). Similar results, from 15 to 20 roots, were obtained on female cuttings treated with 2000 and 6000 ppm IAA, 2000 and 4000 ppm NAA and $2000 \mathrm{ppm}$ IBA. About 5 roots formed on female cuttings treated with IBA 4000 and 6000 ppm. Male cuttings rooted significantly less after treatment with IAA 6000 ppm, NAA 6000 ppm, and IBA 6000 ppm (from 2 to 6 roots). The remaining auxin combinations produced a similar number of roots (14-17).

\section{Root length}

The longest roots, from 85 to $102 \mathrm{~mm}$, were found among rooted female cuttings treated with IAA and IBA of 2000 ppm (Fig. 5). Roots from 50 to $70 \mathrm{~mm}$ were produced on female cuttings treated with NAA 2000 and 4000 ppm, while those rooted after IBA 4000 and 6000 ppm treatments were 18 to $30 \mathrm{~mm}$ long. The roots of the male cuttings were generally longer than that of the female ones, measuring from 60 to $100 \mathrm{~mm}$; only the roots after IAA treatment at $6000 \mathrm{ppm}$ were just over $20 \mathrm{~mm}$.

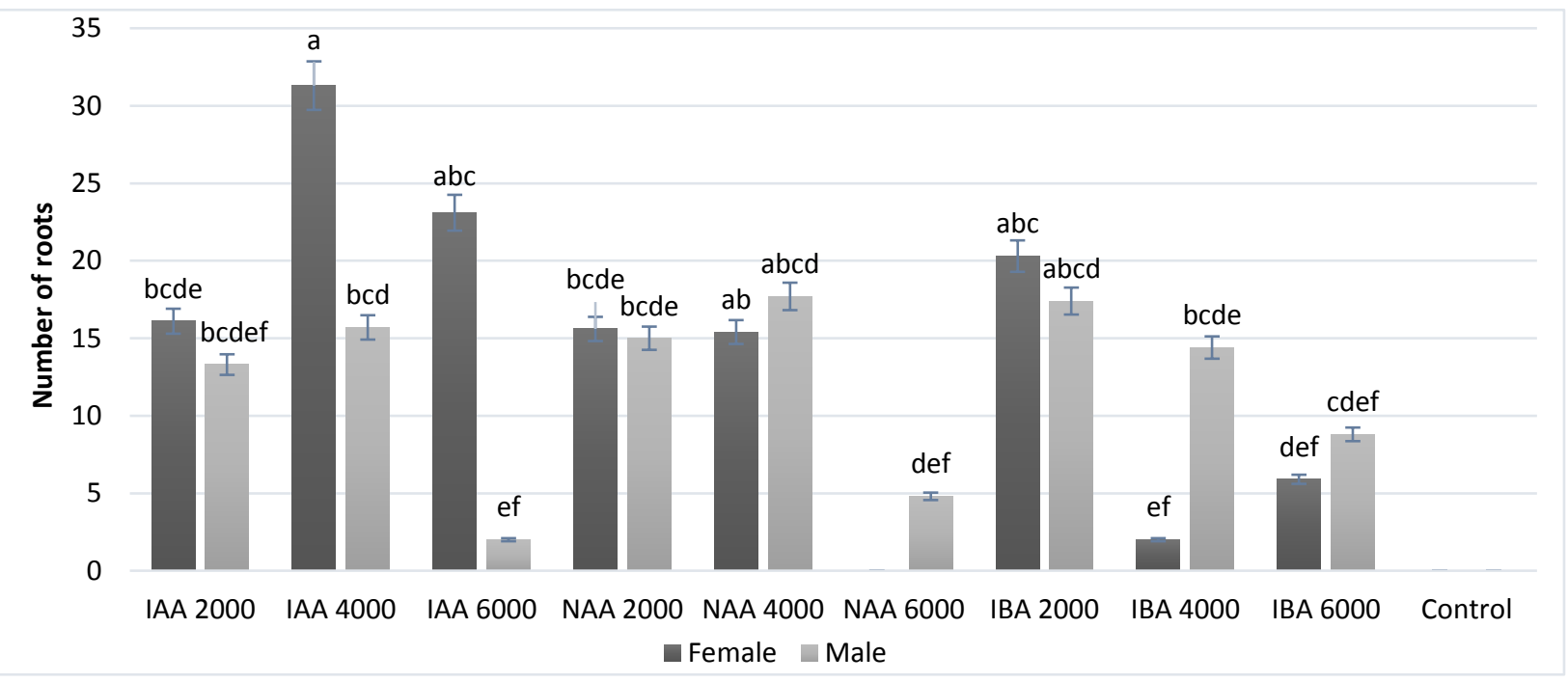

Figure 4. The effect of auxins on the root number of female and male cuttings of L. elimense. Means followed with the same letters do not differ significantly at $\mathrm{p} \leq 0.05$

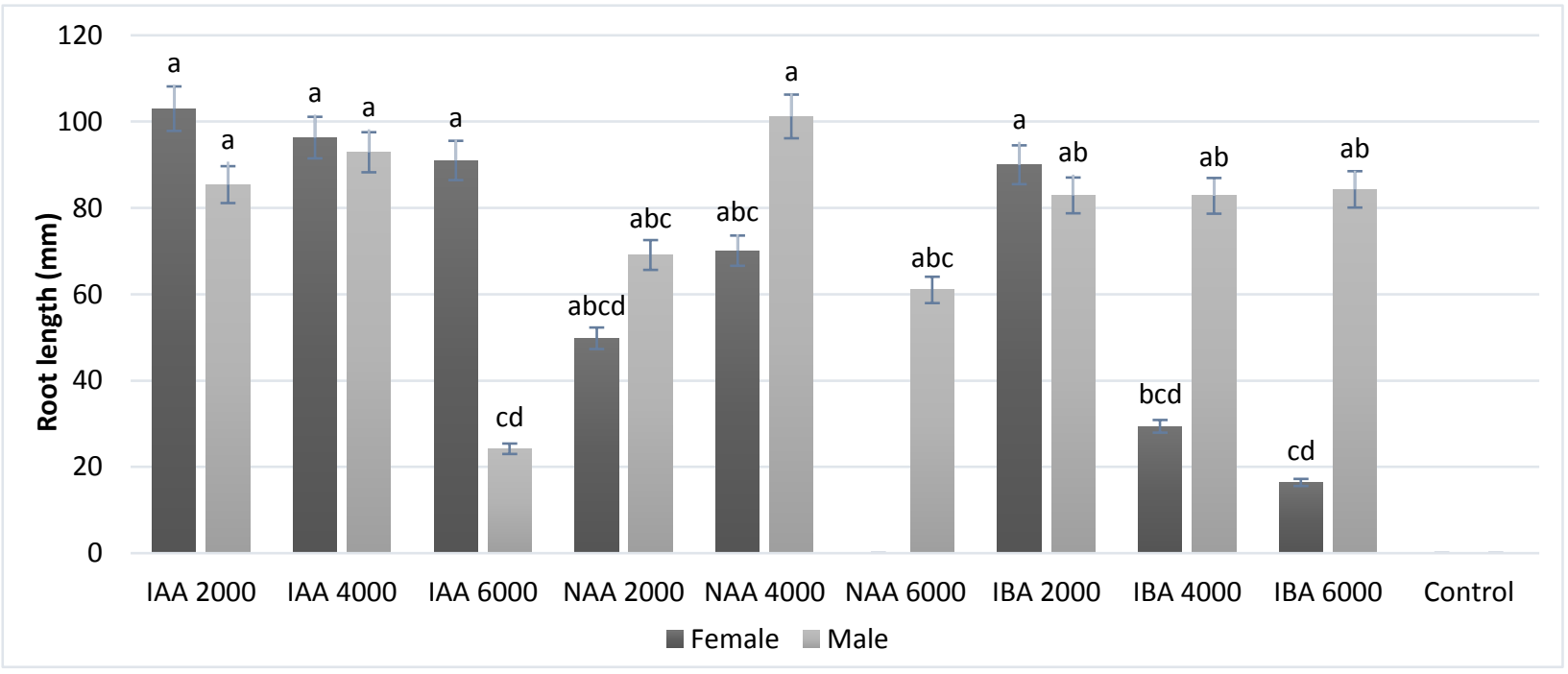

Figure 5. The effect of auxins on the root length of female and male cuttings of L. elimense. Means followed with the same letters do not differ significantly at $\mathrm{p} \leq 0.05$ 


\section{DISCUSSION}

The best results of callusing of female and male cuttings of L. elimense using IAA $4000 \mathrm{ppm}$ are similar to those obtained by Laubscher and Ndakidemi (2008a) on L. laxum, a close relative of L. elimense. According to Blythe et al. (2007) and Gouws et al. (1990), auxins such as IAA are absorbed within the first seconds of application through the basal cut surface of the cutting. It is further speculated that the absorption of a proper amount of hormone depends on species, and it is regulated by the time of exposition to auxin. For plant species difficult to root, an adequate amount of auxin is absorbed in a longer time and rooting is long-time process, which is what has happened in this study. Proteaceae are known as plants difficult to root, compared to several other fynbos species. Ludwig-Müller (2003) investigated rooting potential in relation to peroxidase activity and stated that difficult-to-root Protea showed a higher peroxidase activity in the leaves and middle stem parts, although there was no difference in the uptake of IAA. It can mean that the proper hormone amount is taken up faster in easy-to-root species while difficult-to-root species need a longer period. This could explain why callusing of L L elimense was slow but increased over an extended rooting period of 16 to 18 weeks.

In this study, the cuttings of the female gender rooted the best with the use of IAA, with a maximum at $4000 \mathrm{ppm}$. The male cuttings accepted IBA better, especially at 2000 and $4000 \mathrm{ppm}$. According to reports of Perry and Trueman (1999) NAA should be avoided as auxin for rooting of Conospermum mitchellii to prevent the death of cuttings. Gouws et al. (1990) reported that NAA resulted in tissue dieback at the basal cut surface of Protea species. Similar results were confirmed by Laubscher and Ndakidemi (2008b) in the experiment on the rooting of L. laxum. Results from our study confirmed that NAA is less effective in rooting of L. elimense and should preferably be avoided. An optimal concentration applied could be sufficient for root initiation and development; however, over-optimal concentration, especially in powder preparations, can cause burning of the parenchyma tissue with delay in rooting and or death of the cutting (Janick 2007).
IBA has been reported as the most popular auxin used for cuttings propagation with various degrees of success documented in Proteaceae. The concentration IBA of 2000 ppm (Faruchi et al. 1997; Reinten 2014) was recommended for rooting of Leucadendron species, although most successful results for cone bushes were reported by Ben-Jaacov and Silber (2006) using 2000 ppm of IBA. This finding was later confirmed by Laubscher and Ndakidemi (2008b) with 1000 to $2000 \mathrm{ppm}$ IBA as the most significant in rooting for L. laxum; however, they also confirmed that concentrations higher than 4000 ppm inhibit rooting of cuttings, which was confirmed in our experiment for female cuttings. Rodríguez-Pérez et al. (2001) reported that after 8 weeks of experimentation with IBA at $4000 \mathrm{ppm}$, cuttings of $L$. cordifolium showed satisfactory results, while IBA at $2000 \mathrm{ppm}$ showed the best results after 20 weeks. Peña-Baracaldo et al. (2018) had reported that IBA improved rooting significantly in Leucadendron spp. and according to BenJaacov et al. (1986), the hormone IBA at 2000 ppm should be used for best results in Leucadendron species. However, the results from this study do not agree with Rodríguez-Pérez et al. (2009) who found that IBA at $4000 \mathrm{ppm}$ gave the best rooting results for the propagation of Protea hybrid 'Susara'.

As reported by Pérez-Francés et al. (2001), the cuttings of $L$. discolor and $L$. 'Safari Sunset' should be treated with $4000 \mathrm{ppm}$ of IBA for best results. On the other hand, Laubscher and Ndakidemi (2008b) found that IBA at $1000 \mathrm{ppm}$ showed the best results in the propagation of $L$. laxum whereas Worrall (1976) and Seemann et al. (2013) found that 4000 ppm of IBA gave the best rooting results initially, but delayed toxicity has happened, therefore treatment of 2000 ppm IBA was recommended. Several studies on using IBA rooting hormone were made, but the results were not always consistent. This study found that IBA was the proper auxin to use in rooting of male cuttings, especially at 2000 ppm, but not female cuttings, of L. elimense.

As can be seen from the above results, IAA at $4000 \mathrm{ppm}$ consistently yielded the best results for the female cuttings. These results support Laubscher and Ndakidemi's (2008a) studies, who observed a significant difference in the root length 
and number of roots by IAA concentration. The male cuttings did not show consistent results; the only certain result was that IBA was the best hormone for them in all concentrations with the exception of root number, where 2000 ppm was better than other concentrations. In the previous research by Laubscher and Ndakidemi (2008b), it was shown that IBA at concentrations of $4000 \mathrm{ppm}$ and higher suppressed rooting, and similar results were shown with all hormones used in this experiment.

Due to availability and access to cutting material, it was difficult to complete this experiment during autumn, as was recommended as highly efficient by Ben-Jaacov and Silber (2006), Brown and Duncan (2006), Malan (2012), and Reinten (2014). Although the influence of seasons was not studied in our experiment, it is interesting to note that the collection of cuttings later in the season provided an extended period for cutting propagation of Leucadendron species.

\section{CONCLUSION}

This study established that $L$. elimense can be successfully propagated vegetatively from cuttings using IAA rooting hormone at a concentration of $4000 \mathrm{ppm}$. These results for this species would greatly contribute to developing a cultivation protocol for L. elimense which could aid in saving the species in its natural habitat and support restoration ecology, as well as to introduce this species into the flower market. Hence, future propagation of L. elimense could be explored by using IAA hormone of $4000 \mathrm{ppm}$ concentrations for in-vitro culture purposes.

\section{Conflict of interest}

The authors declare no conflict of interest in this manuscript.

\section{Acknowledgments}

This study was supported with a competitive grant awarded by the Research, Technology and Innovation, Centre for Postgraduate Studies as well as financial support by the Department of Horticultural Sciences, Cape Peninsula University of Technology, Bellville, South Africa.

\section{REFERENCES}

Ben-Jaacov J., Shillo R., Avishai M. 1986. Technology for rapid production of flowering pot-plants of Leucadendron discolor E. Phillips, S. Hutch. Scientia Horticulturae 28(4): 379-387. DOI: 10.1016/0304-4238(86)90112-3.

Ben-Jaacov J., Silber A. 2006. Leucadendron: a major proteaceous floricultural crop. In: Janick J. (Ed.), Horticultural Reviews 32: 167-228. DOI: 10.1002/9780470767986.ch4.

Blythe E.K., Sibley J.L., Tilt K.M., Ruter J.M. 2007. Methods of auxin application in cutting propagation : A review of 70 years of scientific discovery and commercial practice. Journal of Environmental Horticulture 25(3): 166-185. DOI: 10.24266/0738-2898-25.3.166.

Born J., Linder H.P., Desmet P. 2007. The Greater Cape Floristic Region. Journal of Biogeography 34(1): 147-162. DOI: 10.1111/j.1365-2699.2006.01595.x.

Brown N.A.C., Botha P.A. 2004. Smoke seed germination studies and a guide to seed propagation of plants from the major families of the Cape Floristic Region, South Africa. South African Journal of Botany 70(4): 559-581. DOI: 10.1016/s0254-6299(15)30194-0.

Brown N., Duncan G. 2006. Grow fynbos plants. Kirstenbosch Gardening Series. South African National Biodiversity Institute, Cape Town, $240 \mathrm{p}$.

Carolus B., Porter H. 2008. Leucadendron elimense subsp. elimense E. Phillips. South African National Biodiversity Institute. http://pza.sanbi.org/leucadendron-elimense-subsp-elimense (accessed 2.8.21).

Curtis O.E. 2013. Management of Critically Endangered renosterveld fragments in the Overberg, South Africa. Ph.D. Thesis, University of Cape Town, South Africa.

Faber R.J., Laubscher C.P., Rautenbach F., Jimoh M.O. 2020. Variabilities in alkaloid concentration of Sceletium tortuosum (L.) N.E. Br in response to different soilless growing media and fertigation regimes in hydroponics. Heliyon 6; e05479; 9 p. DOI: 10.1016/j.heliyon.2020.e05479.

Faruchi Y., Ackerman A., Gilad S., Ben-Jaacov J., Riov J. 1997. Improved methods for rooting cuttings of Protea obtusifolia. Acta Horticulturae 453: 153157. DOI: 10.17660/actahortic.1997.453.19.

Gouws L., Jacobs G., Strydom D.K. 1990. Factors affecting rooting and auxin absorption in stem cuttings of protea. Journal of Horticultural Science 65(1): 5963. DOI: $10.1080 / 00221589.1990 .11516029$. 
Hall A.V., Veldhuis H.A. 1985. South African Red Data Book: Plants - fynbos and Karoo biomes. South African National Scientific Programmes Report 117, South Africa, $160 \mathrm{p}$.

Holmes P.M., Newton R.J. 2004. Patterns of seed persistence in South African fynbos. Plant Ecology 172(1): 143 158. DOI: $10.1023 / \mathrm{b}$ :vege.0000026035.73496.34

Janick J. (Ed.) 2007. Proteaceous Ornamentals: Banksia, Leucadendron, Leucospermum, and Protea. ISHS. Scripta Horticulturae 5; 160 p.

Laubscher C.P., Ndakidemi P.A. 2008a. The effect of indole acetic acid growth regulator and rooting mediums on rooting of Leucadendron laxum (Proteaceae) in a shade tunnel environment. AmericanEurasian Journal of Agricultural and Environmental Sciences 4(3): 326-331.

Laubscher C.P., Ndakidemi P.A. 2008b. Rooting response under shade using IBA growth regulators and different growth mediums on Leucadendron laxum (Proteaceae) - A commercial cut flower. African Journal of Agricultural Research 3(10): 740-746.

Ludwig-Müller J. 2003. Peroxidase isoenzymes as markers for the rooting ability of easy-to-root and difficult-to-root Grevillea species and cultivars of Protea obstusifolia (Proteaceae). In Vitro Cellular and Developmental Biology - Plant 39(4): 377-383. DOI: 10.1079/ivp2003423.

Malan G. 2012. Protea cultivation: From concept to carton. SUN MeDIA, Stellenbosch, South Africa, 298 p.

Mustart P., Cowling R., Albertyn J. 1997. Southern Overberg. South African Wild Flower Guide 8. Botanical Society of South Africa, 272 p.

Nichols G. 2005. Growing rare plants: a practical handbook on propagating the threatened plants of southern Africa. Southern African Botanical Diversity Network Report 36. SABONET, Pretoria, South Africa.

Peña-Baracaldo F.J., Chaparro-Zambrano H.N., Sierra A., Rodríguez J., Cabezas-Gutiérrez M. 2018. Effect of different substrates and auxins on rooting of Leucadendron sp. (Proteaceae). Revista U.D.C.A. Actualidad y Divulgación Científica 21(2): 385-393. DOI: 10.31910/rudca.v21.n2.2018.968.

Pérez-Francés J.F., Melián-Capote M.N., MartinPérez R., Rodriguez-Pérez J.A. 2001. An anatomical study of adventitious root development in wounded cuttings of Leucadendron discolor and Leucadendron 'Safari Sunset' (Proteaceae). Acta Horticulturae 545: 191-194. DOI: 10.17660/actahortic.2001.545.26.
Perry F., Trueman S.J. 1999. Cutting propagation of Victorian smokebush, Conospermum mitchellii (Proteaceae). South African Journal of Botany 65: 243-244. DOI: 10.1016/s0254-6299(15)30981-9.

Rebelo T. 2001. Proteas. A field guide to the proteas of Southern Africa, 2nd ed. Fernwood Press, Vlaeberg, South Africa.

Reinten E. 2014. Growing proteas: step-by-step guide. Farmer's Weekly Magazine. https://www.farmersweekly.co.za/farm-basics/how-to-crop/growing-proteas/

Rodríguez-Pérez J.A., Vera-Batista M.C., de León-Hernández A.M., Armas-Armas P.C. 2001. Influence of cutting position, wounding and IBA on the rooting of Leucospermum cordifolium 'California Sunshine' cuttings. Acta Horticulturae 545: 171-177. DOI: 10.17660/actahortic.2001.545.23.

Rodríguez-Pérez J.A., Vera-Batista M.C., de LeónHernández A.M., Rodríguez-Hernández I. 2009. Vegetative cutting propagation of Protea hybrid 'Susara' (Proteaceae). European Journal of Horticultural Science 74(4): 175-179.

Schoeman S., Visagie C. 2014. Local history teaching in the Overberg region of the Western Cape : The case of the Elim Primary School. Yesterday and Today 11: 118-132.

Seemann P., Kramm R., Awad G., Ojeda I., Vásquez M.H. 2013. Rooting responses of some Chilean Proteaceae with ornamental potential. Acta Horticulturae 990: 429-436. DOI: 10.17660/actahortic.2013.990.55.

Tansley S.A., Brown C.R. 2000. RAPD variation in the rare and endangered Leucadendron elimense (Proteaceae): implications for their conservation. Biological Conservation 95(1): 39-48. DOI: 10.1016/s0006-3207(00)00015-x.

Viljoen C.C., Jimoh M.O., Laubscher C.P. 2021. Studies of vegetative growth, inflorescence development and eco-dormancy formation of abscission layers in Streptocarpus formosus (Gesneriaceae). Horticulturae 7(6); 120; 16 p. DOI: 10.3390/horticulturae7060120.

Worrall R.J. 1976. Effects of time of collection, growingconditions of mother plants and growth regulators on rooting of cuttings of Telopea speciosissima (Proteaceae). Scientia Horticulturae 5: 153-160. DOI: 10.1016/0304-4238(76)90077-7.

Xego S. 2017. Hydroponic propagation of Siphonochilus aethiopicus: an endangered medicinal plant. M.Tech. Thesis, Cape Peninsula University of Technology, South Africa, 120 p. 